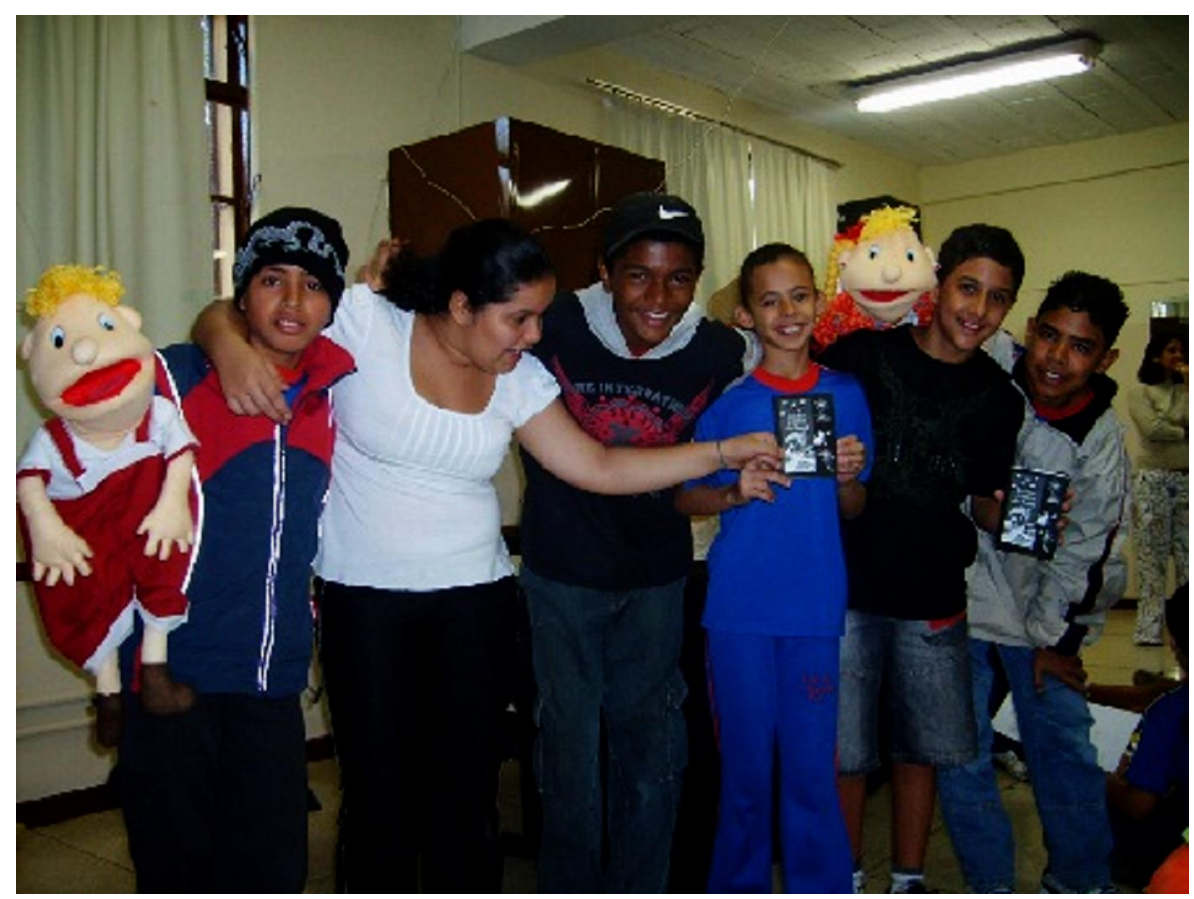

Foto: Juliana Helena Gomes Leal

\title{
Livros de pequeno custo, releituras de alto valor
}

\section{Juliana Helena Gomes Leal}

Doutoranda em Literatura Comparada pela Universidade Federal de Minas Gerais e Mestre em Estudos Literários. Professora de Língua Portuguesa da Rede Municipal de Ensino de BH/MG e de Língua Espanhola da ECFAZ/Receita Federal do Estado de Minas Gerais.

Tomei conhecimento da publicação dos livros de bolso de Literatura Brasileira (em preto e branco) pela Linha Editorial Tela e Texto, do Programa de Ensino, Pesquisa e Extensão A tela e o texto da FALE/UFMG, coordenado pela Prof. Maria Antonieta Pereira, a partir da leitura do artigo "Livros de pequeno custo" veiculado pela revista Presença pedagógica, v. 13, n. 76, de julho/agosto de 2007. Também como aluna, no segundo semestre de 2007, da disciplina "Imagens de leituras e de leitores", do curso de doutoramento em Literatura Comparada da FALE/UFMG, ministrado pela referida professora, tive oportunidade de ler esse artigo. 
Dentre os objetivos que nortearam a criação da Linha Editorial Tela e Texto, o que verdadeiramente me chamou a atenção foi a preocupação com a ruptura da imagem do livro como um artigo de luxo ou, ainda, no meu entender, como um "presente" governamental. Os livrinhos dessa coleção são comercializados pelo valor de R\$1,99 precisamente por terem sido idealizados nesse formato e editados com a liberação de pagamento dos direitos autorais por parte de escritores jovens ou consagrados, bem como por conterem textos de domínio público, o que permite, ao enorme contigente de leitores em potencial pertencente às camadas menos favorecidas da sociedade brasileira, o acesso mais facilitado a esse bem cultural.

Como professora de Língua Portuguesa da Rede Municipal de Ensino de Belo Horizonte, pensei em alguma atividade pedagógica que levasse ao conhecimento dos leitores em formação das instituições públicas de ensino a existência dessas pequenas amostras da literatura e da cultura brasileiras. Também procurei permitir que eles tivesssem a possibilidade de intervir criativamente na materialidade literária dos textos lidos, por meio da formulação de releituras que seriam, posteriormente, compartilhadas e apresentadas a outros leitores da mesma escola.

A idéia se limitava, no início, à contação de algumas estórias da obra Lendas e mitos do Brasil, quarto livrinho da coleção Tela e Texto, para os estudantes de três turmas da antiga $3^{a}$ série, por parte de meus alunos da turma 3111B, primeiro ano do terceiro ciclo ( $6^{a}$ série), da Escola Municipal Maria de Magalhães Pinto. O desenvolvimento desse projeto, no entanto, mostrou-se muito mais interessante e motivador do que poderíamos supor, justamente porque permitimos que os alunos fossem os principais agentes na apresentação do texto escolhido e de suas releituras. Da mesma forma, viabilizamos alguns momentos coletivos de crítica - com o propósito exclusivo de enriquecer, ajustar e adaptar as idéias por eles apresentadas - em relação ao planejamento e à execução das releituras.

Como forma de motivá-los a passar adiante o conteúdo delendas e mitos do Brasil, projetamos, em VHS, algumas das narrações (releituras criativas) feitas pelo já conhecido contador de histórias Roberto Carlos. Vimos surgir, a partir daí 1) o desejo de recontar "A lenda do negrinho do pastoreiro", por meio de uma representação teatral; 2) a necessidade de ilustrar os elementos sígnicos e personagens de "A lenda do surgimento da noite", visando a atrair o interesse dos pequenos espectadores; 3) o desafio de construir um teatrinho de marionetes (cujos personagens foram trabalhosamente desenhados e coloridos pelos próprios integrantes do grupo) 
para representar, dinamicamente, a leitura da "Lenda do Pirarucu" etc.

Aos poucos, foi possível vê-los discutindo com entusiasmo a importância da trilha sonora para dar verossimilhança ao texto narrado ou pensando sobre a relevância de uma adequada leitura em voz alta com suas respectivas entonações. Além disso, passaram a debater acerca do valor que o cenário, o figurino e a gestualidade podem ter na execução da releitura das narrativas por eles lidas. Perceberam que tais recursos são fundamentais para a construção da coerência interna e global do texto literário, na releitura artística por eles construída.

Cabe destacar que a maior parte desses alunos adquiriu, com recursos próprios, o referido livrinho. Mesmo sabendo que a escola possivelmente subvencionaria o projeto, optamos por reforçar o objetivo primeiro do Programa A tela e o texto permitir que os leitores de baixa renda possam adquirir seus próprios livros. Nesse caso, eles experimentaram não somente o sentimento de poder adquirir o objeto cultural livro, mas também se sentiram responsáveis por veicularem seu conteúdo a outros sujeitos, transmitindo-lhes, quizá, o desejo de fazer o mesmo. Essa prática foi, então, multiplicada tanto no que se refere à democratização do acesso ao livro como objeto, quanto ao compartilhamento de sua materialidade textual, que se desenvolveu por meio das releituras.

A relação com o livro, a partir dessa visão, deixou de ter um fim em si mesma e passou a ser vista como um meio que possibilita o intercâmbio das subjetividades resultantes de experiências advindas da interação do aluno-leitor com os textos literários. Noutras palavras, a experiência foi um detonador para a criação de outros textos (o teatral, o gestual, o sonoro, o verbal, o iconográfico etc.). A leitura, pensada assim, ganha força para se livrar dos grilhões da obrigatoriedade, da chatice e da falta de interesse, convertendo-se em uma maneira de situar o sujeito leitor em uma localidade na qual ele é agente ativo. Nesse lugar, sua relação com a literatura passa a ser sinônimo da possibilidade da manifestação de seu eu artístico e criador, que também intervém na realidade (na sua e na de outros sujeitos sociais), provocando uma dupla transformação: a do texto literário em outros e novos produtos culturais (as releituras) e a do próprio leitor que, certamente, será um sujeito diferente a cada nova leitura (releitura) do texto literário. 